\title{
Automated detection and enumeration of fluorescently labelled bacteria with flow cytometry
}

\author{
Linda Mezule', Agata Los ${ }^{2}$ \\ ${ }^{1}$ Riga Technical University, Faculty of Civil Engineering, Department of Water Engineering \\ and Technology. \\ Address: Azenes 16/20-263, Riga, LV-1048, Latvia. \\ ${ }^{2}$ Wrocław University of Technology, Faculty of Chemistry. \\ Address: Wyb. Wyspiattskiego 27 \\ 50-370 Wroclaw, Poland
}

\begin{abstract}
Rapid identification of specific microorganisms in their natural environments is of high importance when their cultivation is either impossible or cannot provide valid results. One of the tools available for such purposes is flow-FISH where classical microscopic identification of microorganisms is combined with an automated enumeration system. Despite the high potential of flow-FISH there are still many unsolved issues to introduce the method. The aim of this research was to determine potential quantification limits of a simple flow-FISH protocol to ensure specific and rapid automated identification of target cells.

The results of the study showed that at optimal hybridization conditions (16 hours of hybridization, 15 minutes post-hybridization washing and $3 \mathrm{ng} / \mu \mathrm{l}$ probe concentration) it is possible to specifically determine all main proteobacteria groups and Grampositive bacteria and discriminate among $\beta$ and $\gamma$ proteobacteria. Detection of $\alpha-$ proteobacteria was not achieved in this study. Despite the promising application potential of flow-FISH, high attention must be made to extensive cell loss (up to 59\%) during preparation of samples for the analyses.
\end{abstract}

Keywords: bacteria, flow cytometry, fluorescence in situ hybridization.

\section{INTRODUCTION}

For many years it has been shown that microbial cultivation on nutrient rich media might not be suitable for detection and enumeration of environmental microorganisms, due to their presence in a nonculturable state [1], specific growth requirements (methanogenic Archaea in anaerobic digestion) or slow division rates [2]. Thus, to effectively enumerate and control overall population dynamics or specific microbial species other methods should be applied.

Fluorescence in situ hybridization (FISH) has become one of the most powerful tools developed in modern microbiology for direct specific detection of target microorganisms in their natural environments [3]. The main advantage of this method is that microorganisms are detected without prior need for cultivation. Moreover, targeting cellular mRNA [4] or effective combination with molecular viability assays [5] has enabled the discrimination of viable target cells among all FISH positive cells. However, the conventional FISH approach is generally linked with fluorescence microscopy which often makes the method time and labor consuming. This in turn makes the method inapplicable for rapid on-site evaluation of environmental systems, e.g., biogas, biofuel stations, natural waters. As an alternative to microscopy flow cytometry has been suggested as a high-throughput quantification method which allow simultaneous phenotypic separation of cell populations based on their surface characteristics. Efficient combination of FISH with flow cytometry (flow-FISH) has been shown for various species, like Staphylococcus aureus [6], lactic acid bacteria [7] and anaerobic fermentation liquid [8]. A substantial feature of flow cytometry is that it is fast, accurate and quantitative in estimating total or viable population counts [9], however, quantitative limits of flow-FISH are still not fully explained. Thus, the aim of this study was to determine potential quantification limits of a simple flow-FISH protocol to ensure specific and rapid automated identification of target cells. To achieve the aim various factors, like, hybridization time, probe concentration, post-hybridization washing time, of the FISH protocol were evaluated prior quantification to 
ensure optimal target signal intensity and avoid any unspecific binding.

\section{MATERIALS AND METHODS}

\section{A. Bacterial cultures and fixation}

Escherichia coli ATCC 25922, Pseudomonas fluorescens ATCC 13525, Burkholderia cepacia LMKK 491, Sphyingomonas paucimobilis LMKK 624 and and Bacillus subtilis ATCC 6633 grown on R2A agar (Oxoid Ltd., UK) were inoculated into tryptone soya broth (Oxoid Ltd., UK) and incubated with constant shaking $(150 \mathrm{rpm})$ overnight or for 18 hours at $30^{\circ} \mathrm{C}$.

For fixation of the cultures a known amount bacterial suspension was inserted into a vial and centrifuged for $2 \mathrm{~min}(2000 \mathrm{~g})$. Then the pellet was twice washed with sterile phosphate buffered saline (PBS: $200 \mathrm{mM} \mathrm{NaH}{ }_{2} \mathrm{PO}_{4} \times \mathrm{H}_{2} \mathrm{O}, 200 \mathrm{mM} \mathrm{NaH}_{2} \mathrm{PO}_{4} \mathrm{x}$ $\mathrm{H}_{2} \mathrm{O}, \mathrm{pH}$ 7.2) and supplied with three volumes of icecold $4 \%$ paraformaldehyde-PBS buffer for 2 hours at $4^{\circ} \mathrm{C}$. After fixation the samples were thrice washed with $\mathrm{PBS}$ buffer and reconstituted in $\mathrm{C}_{2} \mathrm{H}_{6} \mathrm{O}$-PBS mix (3 v/v $\mathrm{C}_{2} \mathrm{H}_{6} \mathrm{O}: 1 \mathrm{v} / \mathrm{v}$ PBS) and stored at $-18^{\circ} \mathrm{C}$ until further use.

\section{B. Cell enumeration}

To determine the total number of cells in the samples microscopy analyses or flow cytometry staining with SYBR ${ }^{\circ}$ Green I nucleic acid stain (Sigma, Germany) were performed. The stain was $1: 100$ diluted in dimethyl sulfoxide (Sigma, Germany), added to the cell suspension and incubated in dark at room temperature for $15 \mathrm{~min}$ before measurements with flow cytometer (section D).

For microscopy fixed suspensions were filtered on 25-mm-diameter $0.2-\mu \mathrm{m}$-pore-size filters $(25 \mathrm{~mm}$ diameter, Track-etched; Whatman plc), washed with sterile distilled water, air-dried and stained with 10 $\mu \mathrm{g} / \mathrm{mL}$ DAPI (4 ,6-diamidino-2- phenylindole, Merck) for 10 minutes, washed with sterile distilled water and air-dried. Cell concentration was determined by epifluorescence microscopy by counting cells in 20 random fields of view (Ex: $340 / 380 \mathrm{~nm}$; Em: $>425$ $\mathrm{nm}$, dichromatic mirror $565 \mathrm{~nm}$, Leica DM, LB).

\section{Sample preparation for Flow-FISH}

A known amount of fixed cells were placed into a microtube and inserted into a dry-block heater $\left(46^{\circ} \mathrm{C}\right)$ for 15 minutes to evaporate ethanol. Then $0.2 \mathrm{~mL}$ of hybridization buffer and probe (labelled with FITC) mix (Table 1) was added to the sample. After vortexing the samples were incubated in the dark for 3 hours at $46^{\circ} \mathrm{C}$. Then $0.5 \mathrm{~mL}$ of pre-warmed washing buffer ( $70 \mathrm{mMNaCl} ; 20 \mathrm{mMTris-HCl}, 5 \mathrm{mM}$ EDTA) was added to the sample, vortexed and centrifuged for $2 \min (2000 \mathrm{~g})$.

After centrifugation $0.6 \mathrm{~mL}$ of the supernatant was removed and replaced with $0.5 \mathrm{~mL}$ of fresh washing buffer. The samples were vortexed and incubated at $48^{\circ} \mathrm{C}$ for 15 minutes. After washing the samples were centrifuged and thrice washed with sterile PBS (pH 8). All time correct follow up of the volumes added and removed was performed. After the last centrifugation PBS ( $\mathrm{pH}$ 8) was added to obtain the total volume of 1 $\mathrm{ml}$ of the sample.

TABLE 1.

OLIGONUCLEOTIDE PROBES USED FOR FLOW-FISH AND CORRESPONDING HYBRIDIZATION CONDITIONS

\begin{tabular}{|c|c|c|c|c|}
\hline Name & $\begin{array}{l}\text { Sequence } \\
5^{\prime}-3^{\prime}\end{array}$ & $\begin{array}{l}\text { Formamid } \\
\text { e, } \%\end{array}$ & Target & Reference \\
\hline EUB338 & $\begin{array}{l}\text { GCTGCCTC } \\
\text { CCGTAGGA } \\
\text { GT }\end{array}$ & 35 & $\begin{array}{l}\text { Domain } \\
\text { Bacteria }\end{array}$ & 10 \\
\hline Non338 & $\begin{array}{l}\text { ACTCCTAC } \\
\text { GGGAGGC } \\
\text { AGC }\end{array}$ & 35 & $\begin{array}{l}\text { Competitor to } \\
\text { EUB338 }\end{array}$ & 10 \\
\hline ALF968 & $\begin{array}{l}\text { GGTAAGGT } \\
\text { TCTGCGCG } \\
\text { TT }\end{array}$ & 20 & $\begin{array}{l}\text { Alfa } \\
\text { proteobacteria }\end{array}$ & 11 \\
\hline BET42a & $\begin{array}{l}\text { GCCTTCCC } \\
\text { ACTTCGTT } \\
\text { T }\end{array}$ & 35 & $\begin{array}{l}\text { Beta } \\
\text { proteobacteria }\end{array}$ & 12 \\
\hline GAM 42a & $\begin{array}{l}\text { GCCTTCCC } \\
\text { ACATCGTT } \\
\mathrm{T}\end{array}$ & 35 & $\begin{array}{l}\text { Gamma } \\
\text { proteobacteria }\end{array}$ & 12 \\
\hline
\end{tabular}

\section{Flow cytometry measurements}

Flow cytometry was performed using CyFlow instrument (Partec, Hamburg, Germany) equipped with $200 \mathrm{~mW}$ laser, emitting a fixed wavelength of $488 \mathrm{~nm}$, and volumetric hardware. Green fluorescence was collected at $520 \mathrm{~nm}$, red fluorescence - at $>615$ $\mathrm{nm}$ and all data were analyzed with the Flomax software (Partec).

The specific instrumental gain settings for these measurements were as follows: green fluorescence $(\mathrm{FL} 1)=430$ and red fluorescence $(\mathrm{FL} 3)=570$. All samples were processed at speed $300 \mu \mathrm{l} / \mathrm{min}$. Where necessary, samples were diluted before measurements in cell-free water for the concentration measured by Cyflow not to increase 1000 cells/min.

\section{RESULTS AND DISCUSSION}

\section{A. Adjustment of flow-FISH}

Generally it is accepted that for probes EUB338 and non338 $0-50 \%$ formamide concentrations are used. To determine the optimal formamide concentration for flow-FISH, formamide series were performed in this study. The results indicated on good signal strength of up to $50 \%$ formamide. Further increase in formamide concentration notably decreased the fluorescence intensity. For further analyses $35 \%$ formamide was used as it was reported previously for epifluorescence microscopy analyses [13] and showed high signal intensity. 
To effectively remove unbound or unspecifically bounded probes post-hybridization washing is performed. Correct adjustment of the washing time ensures optimal positive signal with simultaneous low or no level of unspecific binding [14]. Most commonly used washing times of 10,15 and 20 minutes were tested with the probes EUB338 and non338. The results of flow cytometry showed that the lowest noise ratio was achieved after 15 minutes of washing and represented a false positive cluster of $2.7 \%$ from all positive events recorded. At shorter washing times the false positive level increased to $4.6 \%$. After 20 minutes washing the amount of detectable target cells decreased, thus, increasing the proportion of false positives (3\%). The overall cell loss during washing was neglected due to the hybridization in liquid conditions [15]. Thus, 15 minutes of washing were used in all further tests.
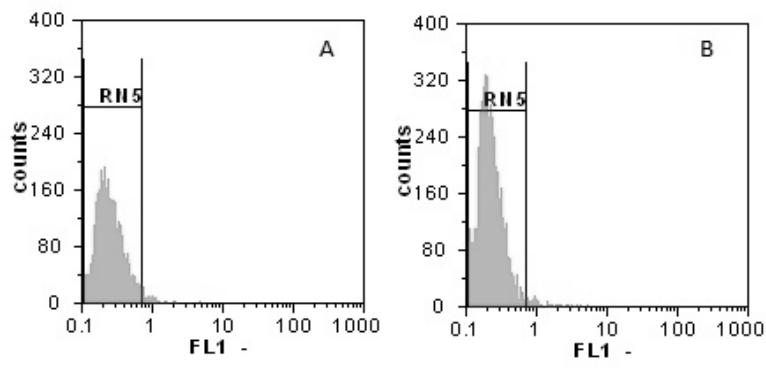

Fig. 1. Amount of fluorescent $E$. coli cells with $1.5 \mathrm{ng} / \mu \mathrm{l}(\mathrm{A})$ and 3 $\mathrm{ng} / \mu \mathrm{l}(\mathrm{B})$ of EUB338-FITC labelled probe. FL1 on X-axis is represented as fluorescence intensity in green channel. RN5 represents the region of interest.

Further the effect of hybridization time and probe concentration was evaluated. Generally $1-5 \mathrm{ng} / \mu \mathrm{l}$ probe concentrations have been recommended for flow-FISH [10]. Comparison of 1.5 and $3 \mathrm{ng} / \mu \mathrm{l}$ showed that better signal intensities are obtained in samples with higher probe concentrations (Fig. 1). At the same time no increase in unspecific staining with non338 was observed when the probe concentration was increased. Prolonged hybridization time of up to 16 hours (when compared to 3 hours) produced higher fluorescence signals within all cell suspensions tested (Fig. 2). For all cells, except B. cepacia, more than tenfold increase was observed, indicating on better binding and more intense signals. Moreover, the observed noise ratio was lower at $16 \mathrm{~h}$ hybridizations and ranged from $0.83 \%$ for S. paucimobilis to $5.6 \%$ for $B$. subtilis. At 3 hours of hybridization the proportion of false positives (hybridized with non338 probe) in B. subtilis samples reached up to $20 \%$.

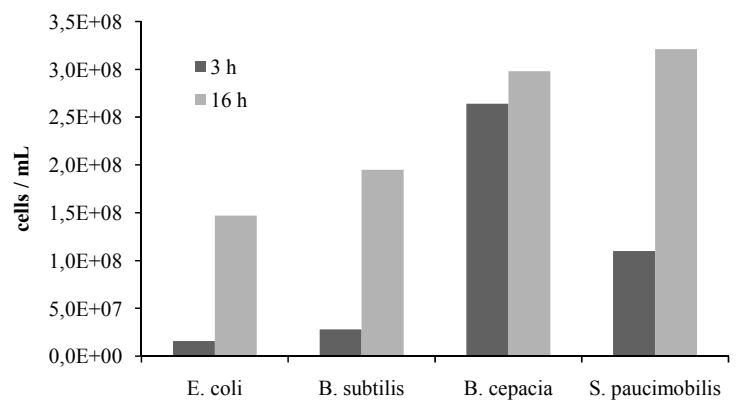

Fig. 2. Amount of cells identified with flow-FISH (probe EUB338) in control suspensions after 3 and 16 hours of hybridization.

Despite apparent improvements in signal intensities and decrease in noise levels after 16 hours of hybridization, it must be taken into account that prolonged hybridizations will limit flow-FISH as a potential tool for rapid analyses. Thus, further prcess optimisation and evaluation of target populatons must be taken into account prior analyses.

\section{B. Evaluation of various probes}

After the set up of potential FISH parameters various probes were tested with the available microbial samples (Table 2). Low or no fluorescence intensities were observed for all bacterial samples when hybridized with no added probe or non338 (Fig. 3). Generally slightly more false positive signals were observed for non338 probe indicating on potential non-specific binding issues. However, the percentage of non-specific binding did not exceed 5\% for Gramnegative and $10 \%$ for Grampositive bacteria tested

Group specific BET42a and GAM42a probes gave positive signals for tested target species. The amount of fluorescent E. coli, B. cepacia and P. fluorescens cells hybridized with BET42a or GAM42a ranged from 73 to $82 \%$ from the fluorescent cells detected with EUB338 ( $p>0.05)$.

TABLE 2.

FLOW-FISH FLUORESCENCE SIGNALS OBSERVED FOR VARIOUS BACTERIA WITH VARIOUS PROBES.

\begin{tabular}{|c|c|c|c|c|c|}
\hline \multirow[b]{2}{*}{ Species } & \multirow{2}{*}{$\begin{array}{l}\text { Proteo } \\
\text { bacteria } \\
\text { group }\end{array}$} & \multicolumn{4}{|c|}{ Probe } \\
\hline & & $\begin{array}{l}\text { EUB } \\
338\end{array}$ & $\begin{array}{l}\text { BET } \\
42 a\end{array}$ & $\begin{array}{l}\text { GAM } \\
42 \mathrm{a}\end{array}$ & $\begin{array}{l}\text { ALF } \\
968\end{array}$ \\
\hline E. coli & $\gamma$ & + & - & + & - \\
\hline P. fluorescens & $\gamma$ & + & - & + & - \\
\hline B. subtilis & - & + & - & - & - \\
\hline B. серасіа & $\beta$ & + & + & - & - \\
\hline S. paucimobilis & $\alpha$ & + & - & $+*$ & - \\
\hline
\end{tabular}

* non-target fluorescence 

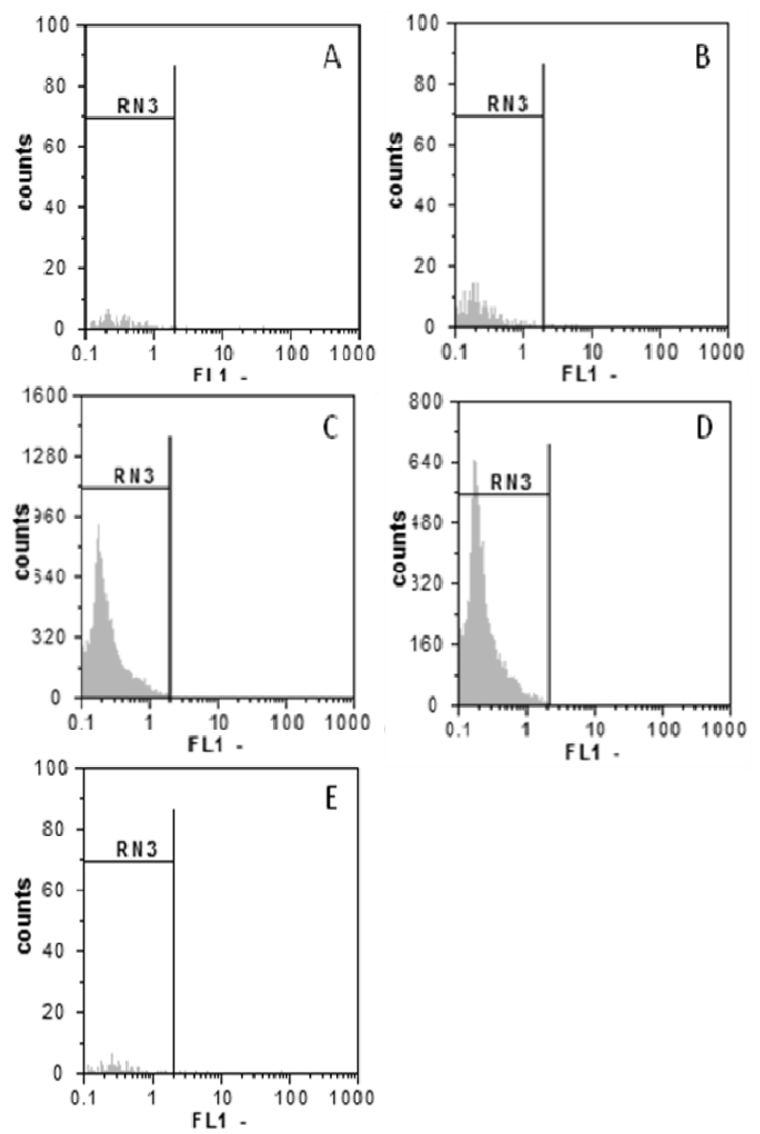

Fig. 3. Pseudomonas fluorescens fluorescence signals when hybridized with no probe (A), non338 (B), EUB338 (C), GAM42a (D) and BET42a (E). FL1 on X-axis is represented as fluorescence intensity in green channel.

No fluorescent cells were observed with probe ALF968. Fluorescence intensity for $S$. paucimobilis ( $\alpha$-proteobacteria) hybridized with ALF968 was significantly lower $(\mathrm{p}<0.05)$ than fluorescence observed with EUB338. At the same time epifluorescence microscopy produced fluorescent $S$. paucimobilis cells indicating on problems associated only with flow-FISH and not FISH protocol in general. Along with the optimization of the protocol, the application of other available $\alpha$-proteobacteria targeting probes can be taken into account [16]. Further analyses with $S$. paucimobilis produced fluorescent signals when hybridized with GAM42a (Table 2). The amount of the observed fluorescent objects constituted 33\% from all identified objects with EUB338, indicating on a potential problem in flow-FISH. No such fluorescence was observed with epifluorescence microscopy.

\section{Enumeration of cells with flow-FISH}

Apart from high specificity, the main issue in having flow-FISH as a quantitative method is to omit or replace treatment steps which produce high decrease in total cell counts. One of the identified treatments include post-hybridization washing where the samples have to be centrifuged and re-suspended many times [10]. To evaluate cell losses during flowFISH treatment cells were collected after hybridization, after $1^{\text {st }}$ and $2^{\text {nd }}$ post-hybridization washing, after final washing with PBS and after resuspending (final). The collected samples were directly stained with SYBR green and enumerated with flow cytometry (Fig. 4) to determine total counts.

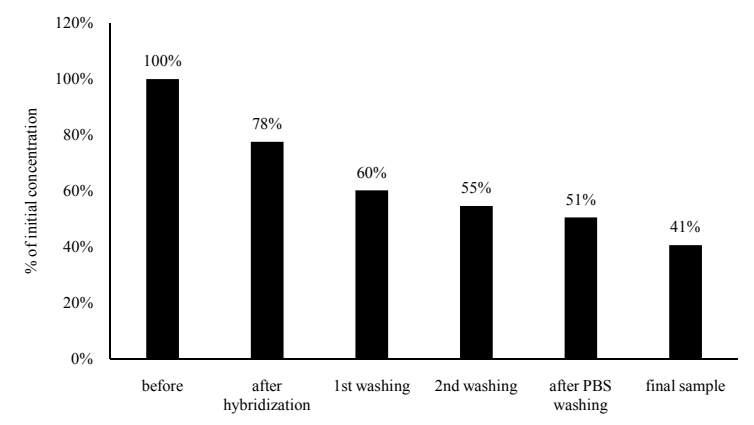

Fig. 4. The amount of cells lost during sample preparation for flow-FISH.

The results showed that there is no single treatment step which produce significant cell decrease. A mere decrease is observed within all treatments and resulted in $59 \%$ of lost cells during sample preparation for flow-FISH. When analysing samples with high cell content, e.g. biogas, this might not affect the overall outcome of the test result, however, due to the detection limits of the method itself (around $10^{3} / \mathrm{ml}$ ) [17] even minor cell loss in samples with low density target cells might seriously affect the results.

\section{CONCLUSION}

It is possible to detect positive flow-FISH signals in positive samples. Background noise and false positives can be easily distinguished with flow cytometry, thus, rapid automated identification of target cells was possible. At the moment the quantification limits of the method are target cell counts above $105 / \mathrm{ml}$ because of high (around 59\%) overall cell decrease during sample preparation for flow-FISH.

An optimal FISH protocol suitable for flow cytometry was developed. 16 hours of hybridization in liquid conditions and 15 minutes of post-hybridization washing allowed to obtain the highest positive signals with the lowest noise. Flow-FISH showed to be a good tool to distinguish among various classes of bacteria - $\gamma$-proteobacteria, $\beta$-proteobacteria and Grampositive bacilli were differentiated correctly. However, high non-specific binding was observed for $\alpha$-proteobacteria.

Flow-FISH at its current stage seems to be a promising tool for automated assessment of microbial cultures with high initial cell concentration in nutrient rich environments, e. g. biogas systems. However, further research for application of this method in low- 
nutrient environments and its potential rapidity is still necessary.

\section{$\mathrm{V}$ ACKNOWLEDGMENTS}

This work has been supported by ESF project „Involvement of Human Resources for Development of Integrated Renewable Energy Resources Energy Production System", No. Nr.2013/0014/1DP/ 1.1.1.2.0/13/APIA/VIAA/026.

Ms Kristina Tihomirova is acknowledged for assistance with flow cytometry measurements.

\section{REFERENCES}

[1] J. D. Oliver. "Recent findings on the viable but nonculturable state in pathogenic bacteria." FEMS Microbiology Reviews, vol. 43, pp. 415-425, Jul. 2010.

[2] J. G. Ferry. Methanogenesis: ecology, physiology, biochemistry \& genetics. New York: Chapman \& Hall, 1993, pp. 1-406.

[3] J. Pernthaler, F.O. Glöckner, W. Schönhuber, R. Amann "Fluorescence in situ hybridization with rRNA-targeted oligonucleotide probes," in Methods in Microbiology: Marine Microbiology, vol. 30, J. Paul, Ed. London: Academic Press Ltd, 2001, pp. 1-31.

[4] A. Pernthaler, R. Amann. "Simultaneous fluorescence in situ hybridization of mRNA and rRNA in environmental bacteria." Applied and Environmental Microbiology, vol. 70, pp. 54265433, Sept. 2004.

[5] L. Mezule, S. Larsson, T. Juhna. „Application of DVC-FISH method in tracking Escherichia coli in drinking water distribution networks." Drinking Water Engineering Science, vol. 6, pp. 25-31, Apr. 2014

[6] H. Hartmann, H. Stender, A. Schäfer, I.B. Autenrieth, V.A.J. Kempf. "Rapid identification of Staphylococcus aureus in blood cultures by a combination of fluorescence in situ hybridization using peptide nucleic acid probes and flow cytometry." Journal of Clinical Microbiology, vol. 43, pp. 4855- 4857, Sept. 2005

[7] U. Friedrich, J. Lenke. "Improved enumeration of lactic acid bacteria in mesophilic dairy starter cultures by using multiplex quantitative real-time PCR and flow cytometry-fluorescence in situ hybridization." Applied and Environmental Microbiology, vol. 72, pp. 4163-4171, June 2006.

[8] E. Nettmann, A. Fröhling, K. Heeg, M. Klocke, O. Schlüter, J. Mumme. "Development of a flow-fluorescence in situ hybridization protocol for the analysis of microbial communities in anaerobic fermentation liquor." $B M C$ Microbiology, vol. 13, pp. 1-15, 2013.

[9] F.A. Hammes, T. Egli. "New method for assimilable organic carbon determination using flow-cytometric enumeration and a natural microbial consortium as inoculum." Environmental Science and Technology, vol. 39, pp. 3289-3294, May 2005.

[10] G. Wallner, R. Amann, W. Beisker. "Optimizing fluorescent in situ hybridization with rRNA-targeted oligonucleotide probes for flow cytometric identification of microorganisms." Cytometry, vol. 14, pp.136-143, July 1992.

[11] A. Neef. "Anwendung der in situ Einzelzell-Identifizierung von Bakterien zur Populationsanalyse in komplexen mikrobiellen Biozönosen." Doctoral thesis, Technische Universität München, Germany, 1997.

[12] W. Manz, R. Amann, W. Ludwig, M. Wagner, K.-H. Schleifer. "Phylogenetic oligodeoxynucleotide probes for the major subclasses of Proteobacteria: Problems and solutions." Systematic and Applied Microbiology, vol. 15, pp. 593-600, Dec. 1992.

[13] K. Rugele, L. Mezule, B. Dalecka, S. Larsson, J. Vanags, J. Rubulis. "Application of fluorescent in situ hybridization for monitoring methanogenic archaea in acid whey anaerobic digestion." Agranomy Research, vol. 11, pp. 373-380, 2013.

[14] A. Moter, U. B. Göbel. "Fluorescence in situ hybridization (FISH) for direct visualization of microorganisms." Journal of Microbiological Methods, vol. 41, pp. 85-112, Apr. 2000.

[15] R. Sekar, B. M. Fuchs, R. Amann, J. Pernthaler. "Flow sorting of marine bacterioplankton after fluorescence in situ hybridization." Applied and Environmental Microbiology, vol. 70, pp. 6210-6219, Oct. 2004.

[16] A. Loy, F. Maixner, M. Wagner, M. Horn. "probeBase - an online resource for rRNA-targeted oligonucleotide probes: new features 2007." Nucleic Acids Research, vol. 35, pp. D800-D804, Jan. 2007.

[17] A. Rohde, J. A. Hammerl, B. Appel, R. Dieckmann, S. Al Dahouk. "FISHing for bacteria in food - A promising tool for the reliable detection of pathogenic bacteria?" Food Microbiology, Vol. 46, pp. 395-407April 2015. 